\title{
PATTERNS IN SHORELINE VEGETATION AND SOILS AROUND LAKE MOHAVE, NEVADA AND ARIZONA: IMPLICATIONS FOR MANAGEMENT
}

\author{
Nita Tallent ${ }^{1}$, Maliha $\mathrm{Nash}^{2}$, Chad L. Cross ${ }^{3}$, and Lawrence R. Walker 4
}

ABstract.-Lake Mohave, on the lower Colorado River in Nevada and Arizona, was created by the construction of Davis Dam for power generation, flood control, and water supply. Management has led to the periodic lowering of the water level of the reservoir (drawdown), such that it reveals a gradient of zones around the margins of the reservoir that range from frequently inundated to frequently dry. The initial filling of Lake Mohave flooded the preexisting native riparian woodlands of Populus-Salix (cottonwood-willow), creating a new shoreline and plant community. We analyzed the spatial distribution of the plant species that dominate the plant community (i.e., native Salix gooddingii C.R. Ball [Goodding's willow] and nonindigenous Tamarix ramosissima Ledeb. [saltcedar]) and the soil components to discern patterns. Data analyses and modeling indicate that there are 3 emergent patterns in the distribution and composition of vegetation and soils. First, even though both S. gooddingii and T. ramosissima were present in the inundated zones, there were more mature $S$. gooddingii individuals in the frequently inundated reaches, while T. ramosissima presence and cover increased with distance from the water's edge. Salix gooddingii seedlings were not observed, but T. ramosissima seedlings were present in all zones. The only regeneration of $S$. gooddingii was vegetative. Naturally occurring Populus fremontii S. Watson (Fremont cottonwood) was completely absent in the drawdown and upland plant communities. Second, soil salinity and $\mathrm{pH}$ values range from 49.4 to $0 \mathrm{dS} \cdot \mathrm{m}^{-1}$ and 6.4 to 9.4 , respectively, and varied significantly with landform type and geographic location along the reservoir. Patterns in soil chemistry may be related to shore geomorphology that either shelters or exposes soils to wave action, which mechanically agitates, aerates, and flushes soils. Presence of Salix gooddingii in the frequently inundated zones and the co-occurrence of T. ramosissima and relatively high soil salinity concentration reflect patterns among plant flood tolerance and soil responses to periodic inundation. While reasons for the absence of $P$. fremontii are unknown, the absence of $S$. gooddingii seedlings may be related to the fact that seed release coincides with the period when the reservoir is at its highest, thereby limiting recruitment. Third, the only regeneration of $S$. gooddingii appeared to have occurred following herbivory (Castor canadensis Kuhl [North American beaver]) and wind damage. We conclude with suggestions for the conservation of novel riparian ecosystems as surrogates for lost native ecosystems. These suggestions include manipulating reservoir water levels to simulate natural fluvial processes so that nonnative plant establishment is inhibited, excessive soil salts are flushed from the system, and native transplants can be established.

Resumen._El Lago Mohave, en la parte baja del Río Colorado en Nevada y Arizona, E.U.A., fue creado por la construcción de la presa Davis para la generación de electricidad, control de inundaciones y abastecimiento de agua. Su manejo ha causado el descenso periódico del nivel del agua del embalse (reducción) de modo que revela un gradiente de zonas alrededor de la orilla del embalse que varían desde las frecuentemente inundadas hasta las frecuentemente secas. Al llenar por primera vez el Lago Mohave, se inundó el bosque preexistente nativo y ribereño de Populus-Salix (álamos y sauces), creando nuevas riberas y nuevas comunidades de plantas en sus orillas. Analizamos la distribución espacial de las especies que dominan la comunidad de plantas (i.e., la especie nativa Salix gooddingii C.R. Ball [el sauce de Goodding] y la invasora Tamarix ramosissima Ledeb. [tamarisco]) así como los componentes del suelo para discernir patrones entre la vegetación y los suelos. El análisis de datos y la modelación indican que hay tres patrones emergentes en la distribución y composición de la vegetación y los suelos. Primero, a pesar de que tanto S. gooddingii como T. ramossisima estuvieron presentes en las zonas inundadas, hubo más individuos maduros de S. gooddingii en las zonas frecuentemente inundadas; en cambio, la presencia y cobertura de T. ramosissima aumentó a medida que aumentaba la distancia de la orilla. No se observaron plántulas de S. gooddingii, mientras que plántulas de T. ramosissima estuvieron presentes en todas las zonas. La única regeneración de S. gooddingii fue vegetativa. Populus fremontii S. Watson [álamo], que ocurre de manera natural, estuvo totalmente ausente en las comunidades de plantas que habitan las zonas donde se ha reducido el nivel del agua y en tierras altas. Segundo, la salinidad y los valores de $\mathrm{pH}$ del suelo variaron de $49.4 \mathrm{a} 0 \mathrm{dS} \cdot \mathrm{m}^{-1}$ y de 6.4 a 9.4, respectivamente, y variaron substancialmente en distintos tipos de formación geológica y en distintas ubicaciones geográficas alrededor del embalse. Los patrones en la composición química del suelo podrían estar relacionados con la geomorfología de la ribera, la cual puede proteger los suelos o exponerlos a la acción de las olas que mecánicamente agitan, airean y humedecen los suelos. La presencia de Salix gooddingii en las zonas frecuentemente inundadas y la

${ }^{1}$ Mojave Desert Network Inventory \& Monitoring, U.S. Department of Interior, National Park Service, 601 Nevada Way, Boulder City, NV 89005. E-mail: nita_tallent-halsell@nps.gov

${ }^{2}$ Environmental Sciences Division, U.S. Environmental Protection Agency, 944 E. Harmon Ave., Las Vegas, NV 89119.

${ }^{3}$ SWCA Environmental Consultants, Las Vegas Office, 7373 Peak Dr., Suite 170, Las Vegas, NV 89128.

${ }^{4}$ Department of Life Sciences, University of Nevada, Las Vegas, Box 454004, 4505 So. Maryland Parkway, Las Vegas, NV 89154-4004 
coincidencia de T. ramosissima y una concentración de sales en el suelo relativamente alta reflejan patrones de la resistencia a inundaciones por parte de las plantas y los efectos en los suelos de las inundaciones periódicas. Aunque se desconocen las causas de la ausencia de $P$. fremontii, la ausencia de plántulas de $S$. gooddingii podría estar relacionada con el hecho de que la dispersión de semillas coincide con el periodo en que el embalse alcanza su nivel máximo, limitando de esta manera el reclutamiento. Tercero, la única regeneración de $S$. gooddingii parece haber ocurrido después de la herbivoría (Castor canadensis Kuhl [castor americano]) y de los daños ocasionados por el viento. Concluimos con sugerencias para la conservación de los ecosistemas ribereños nuevos como reemplazos de los ecosistemas originales perdidos. Éstas incluyen el manipular el nivel del agua en los embalses para similar procesos fluviales naturales y así impedir que se establezcan las plantas invasoras, limpiar del sistema las sales excesivas en el suelo y permitir que se establezcan plantas nativas que hayan sido transplantadas.

Lake Mohave, an aridland reservoir on the border of Nevada and Arizona in the southwestern United States (Fig. 1), was formed following the construction of Davis Dam in 1953 on the lower Colorado River. Davis Dam was constructed to generate power, control floods, and supply water for downstream urban, industrial, and agricultural use (Bureau of Reclamation 2011). Construction of the Davis Dam altered the natural flow of the Colorado River downstream of the Hoover Dam. Management of the river has led to periodic lowering of the reservoir water level (drawdown), such that a gradient of zones has developed around the margins of the reservoir. The zones range from frequently inundated to frequently dry (Fig. 2).

The filling of Lake Mohave flooded the preexisting native woodlands dominated by Populus fremontii (Fremont cottonwood) and Salix gooddingii (Goodding's willow) and created a new shoreline around reservoir margins at higher elevations previously dominated by the desert shrub Larrea tridentata (DC.) Colville (creosote bush). The plant communities of the new shoreline are comprised of native S. gooddingii and nonindigenous Tamarix ramosissima (saltcedar). However, there is a complete absence of $P$. fremontii (C. Deuser and J. Haley, Lake Mead National Recreation Area, Nevada, personal communication, 1996), the pioneer tree species that co-occurred with $S$. gooddingii along the Colorado River prior to regulation by dams (Braatne et al. 1996). In this paper, a riparian ecosystem is the terrestrial environ adjacent to the reservoir whose freshwaters provide soil moisture sufficient to support the growth of phreatophytic vegetation (modified from Warner and Hendrix 1984). Salix gooddingii and P. fremontii are obligate phreatophytes (i.e., a deep-rooted, "water-loving" plant that obtains its water from permanent ground supply or capillary fringe [hyporheic zone] of streams, rivers, lakes, and reservoirs; Braatne et al. 1996, Smith et al.
1997, 1998). Tamarix ramosissima is a facultative phreatophyte and, thus, can obtain water at lower soil water potential than native riparian trees (Smith et al. 1997).

Notably, the plant communities currently occurring around Lake Mohave are perceived by the public and land managers as valuable systems that provide habitat for native plant species and wildlife as well as scenic landscapes that are as culturally pleasing as they are unique to arid environments. Throughout arid regions worldwide, there are novel riparian ecosystems that have species compositions and relative abundances that have not occurred previously within a given biome (Hobbs et al. 2006). Many of these ecosystems have arisen along human-generated water-bodies and waterways, such as stockponds in Oklahoma (Kelting and Penfound 1950, Penfound 1953) and Kentucky (Hall and Smith 1955), Colorado gravel pits and diversion canals (Mahoney and Rood 1998, Roelle and Gladwin 1999, Roelle et al. 2001, Crifasi 2005), reservoirs and rivers in Montana (Johnson 2002), Australian lakes (Williams 2000), and the lower Colorado River reservoir Lake Mohave on the border of Nevada and Arizona (Tallent-Halsell 1998). Direct (e.g., dam construction) and indirect human interventions (e.g., construction of dispersal barriers) have resulted either in major changes to the abiotic environment or a decrease in the original propagule species pool, both of which can prevent the reestablishment of preexisting species assemblages and alter the biogeochemistry of the system (Nilsson and Berggren 2000, Johnson 2002, Crifasi 2005).

Efforts to introduce native $S$. gooddingii and $P$. fremontii around the lower Colorado River reservoir Lake Mohave, in an attempt to expand and sustain novel but aging woodlands, have not been successful $(<1 \%$ establishment of introduced saplings, C. Deuser and J. Haley, Lake Mead National Recreation Area, Nevada, personal communication, 1996). The 


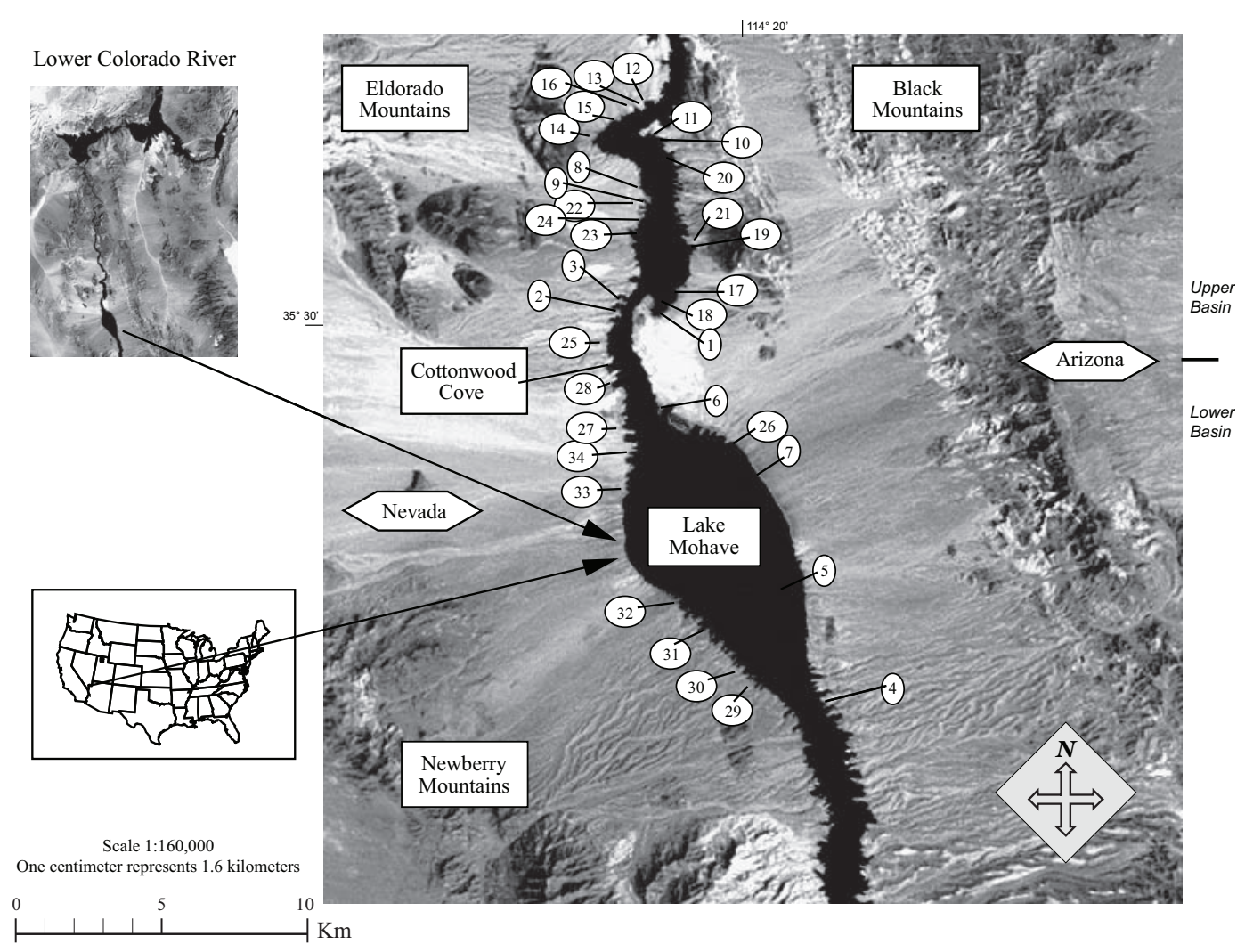

Fig. 1. Locations of 34 study sites at Lake Mohave in the Lake Mead National Recreation Area in Nevada and Arizona. Descriptions of numbered sites are provided in the Appendix.

transplants' failure to establish was due, in part, to the fact that native $S$. gooddingii experiences high mortality and reduced biomass under flood conditions (Tallent-Halsell and Walker 2002). In addition, revegetation efforts may have been further compromised by a suite of factors that affect riparian ecosystems throughout the Southwest, such as the rapid colonization by $T$. ramosissima (Anderson 1996) and riparian soil salinization (Vandersande et al. 2001). Foraging on $S$. gooddingii and P. fremontii transplants by Castor canadensis (North American beaver; Rosell et al. 2005) may also have limited the survival of transplants (C. Deuser and J. Haley, Lake Mead National Recreation Area, Nevada, personal communication, 1996).

Little is known about the ecology of novel riparian ecosystems; therefore, we designed a study to better understand the resulting plant distributions and factors affecting these distributions in the riparian zone along Lake Mohave. Our 3 main objectives were to (1) describe the pattern of S. gooddingii and T. ramosissima cover; (2) describe the pattern of soil salinity, nutrients, and texture; and (3) relate these patterns to a suite of variables, including landform (beaches in sheltered coves or line beaches that were exposed), geographic location (eastern or western bank, northern or southern basin), herbivory, presence of native vegetation, and location of plants from the water's edge. Our study contributes information about the ecology of riparian ecosystems on reservoirs in deserts and the environmental factors that shape them.

\section{Methods \\ Study Area}

Lake Mohave is a long $(108 \mathrm{~km})$ and narrow (average $6.4 \mathrm{~km}$ ) reservoir with a total surface area of $114 \mathrm{~km}^{2}$ (Bureau of Reclamation 2011). The release of water through Davis Dam (drawdown) creates a distinct gradient of zones that 


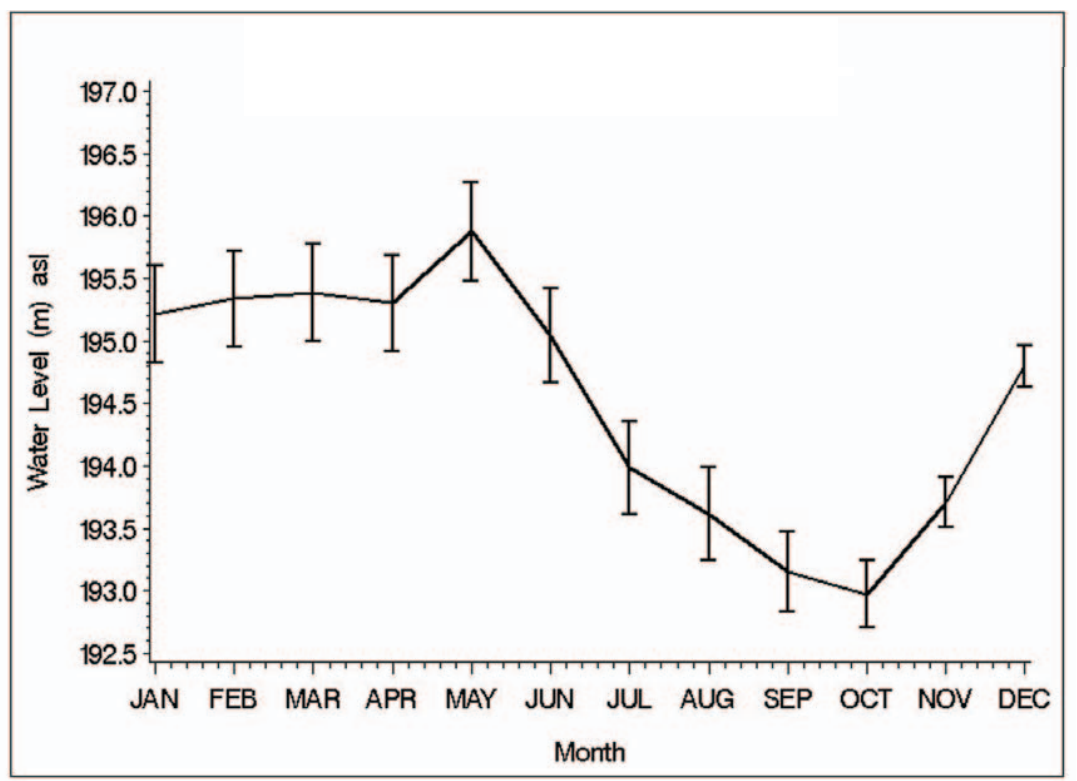

Fig. 2. Hydrograph characterizing the hydrologic regime of Lake Mohave (1950-2007) and illustrating that water level drops approximately $3 \mathrm{~m}$ beginning in September and rises again in January. The y-axis is the mean water level, and error bars depict one standard deviation around the mean.

TABLE 1. Characteristics of groupings of sites at Lake Mohave, Nevada and Arizona, USA. Sample sizes are in parentheses.

\begin{tabular}{|c|c|c|}
\hline Characteristic & $\begin{array}{c}\text { Grouping } 1 \\
(n)\end{array}$ & $\begin{array}{c}\text { Grouping } 2 \\
(n)\end{array}$ \\
\hline Bank $^{\mathrm{a}}$ & West (21) & East (13) \\
\hline Salix ${ }^{\mathrm{b}}$ & Present (18) & Absent (16) \\
\hline Landform $^{\mathrm{c}}$ & Exposed (13) & Cove (21) \\
\hline Herbivoryd & Present $(20)$ & Absent (14) \\
\hline Basine & Upper (21) & Lower (13) \\
\hline $\begin{array}{l}\text { Location in the } \\
\text { drawdown }\end{array}$ & Band $A^{g}$ & Band Bg \\
\hline
\end{tabular}

abank $=$ western or eastern side of river

balix $=$ presence of Salix gooddingii.

${ }^{c}$ Landform $=$ either exposed (line beaches) or (sheltered) coves; see text for further explanation.

${ }^{\mathrm{d}}$ Herbiovry $=$ presence or absence of herbivory

e Basin $=$ located in the upper northern or lower southern basin

$\mathrm{f}_{\text {Location in the drawdown }}$ group based on the distance from waters at maximum drawdown; see text for further explanation.

gSee Figs. 4 and 5 for sample size.

is approximately $25 \mathrm{~m}$ in width from minimum to maximum water level, depending on the slope of the shoreline. These zones range from frequently inundated to frequently dry. The maximum and minimum lake elevations for Lake Mohave are $197 \mathrm{~m}$ and $193 \mathrm{~m}$, respectively (Fig. 2). This study was conducted in the 2 widest basins and interconnecting area where the gradient of zones is most evident and where the largest stands of native, woody vegetation occur (Appendix; Fig. 1).
Our sites were grouped by side of the lake (east or west), location in the basin (upper [northern] or lower [southern]), and landform type (Fig. 1). The landform types were defined as sheltered coves and exposed line beaches. Sheltered coves were defined as inlets that were sheltered from the wind on 3 sides by upland hills and that had shorelines at least $50 \mathrm{~m}$ away from the mouth of the inlet. Exposed line beaches were characterized as unbroken, linear stretches of shore with full exposure to wind from all sides. In addition, we grouped the sites by whether we observed S. gooddingii, as well as evidence of beaver foraging and activity (henceforth referred to as herbivory).

Additionally, we divided the data into 2 groups based upon whether the sampling point was located 0-25 m (band A) or 26-50 m (band B) from the water's edge at maximum drawdown (Table 1). Band A was characterized by having been frequently inundated (i.e., approximately 9 months prior to the sample period), whereas band B was characterized by having been frequently dry throughout the year.

To select study sites we divided the shoreline of the 2 widest basins and interconnecting area into 264 segments, each $1 \mathrm{~km}$ long. From these segments, $20 \%(n=53)$ were randomly selected as potential locations from 


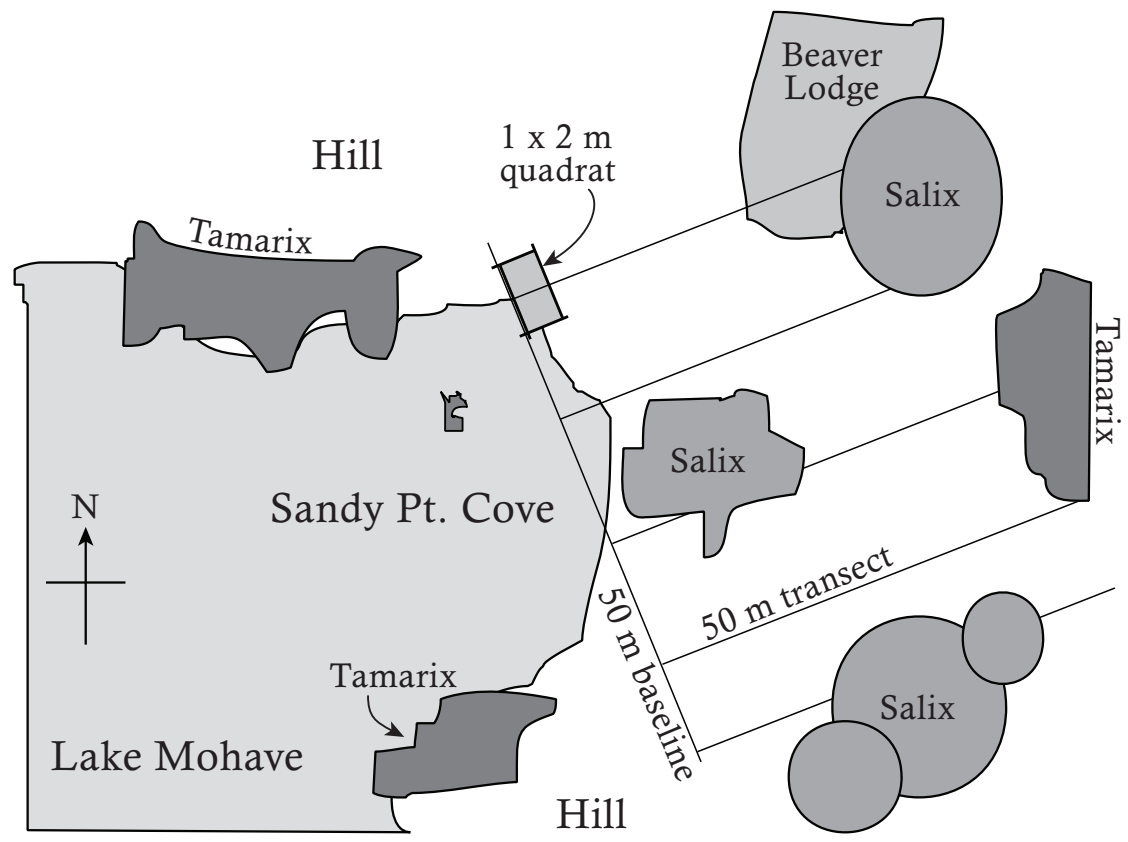

Fig. 3. Schematic representing the field sampling design at Lake Mohave.

within which to randomly establish $50 \times 50-\mathrm{m}$ $\left(2500-\mathrm{m}^{2}\right)$ study sites along the shoreline (henceforth referred to as "sites"). When sites with steep slopes $(>10 \%)$, rock walls, compacted soils, or extensive cobble $(>80 \%$ cover of cobble $>6 \mathrm{~cm}$ in diameter) were excluded, 34 sites remained (Appendix 1; Fig. 1).

The sites were located on loamy sand alluvium derived from basalt (Hoffman and Jonez 1972), and soils were shallow, hyperthermic aridisols (Natural Resource Conservation Service 1993) that had been intermittently inundated for at least 60 years. The climate is typical of the southern Mojave Desert, with hot summers and cool winters (MacMahon and Wagner 1985). The yearly mean precipitation, though highly variable, is $109 \mathrm{~mm}$; the majority of the precipitation falls in winter, with rare rainfall events occurring during the summer. The mean monthly high and low temperatures range from $18{ }^{\circ} \mathrm{C}$ and $1{ }^{\circ} \mathrm{C}$ in January to $44^{\circ} \mathrm{C}$ and $27^{\circ} \mathrm{C}$ in July (National Park Service 2011).

\section{Field Measurements}

At each of the 34 sites, a 50-m-long baseline was placed parallel to the shoreline at $193 \mathrm{~m}$ above sea level (asl), which was the minimum water level during our study period (Fig. 3).
Five transects $(2 \times 50 \mathrm{~m})$ were placed perpendicular to the plot baseline at intervals of $10 \mathrm{~m}$, moving up from the wetter (band A) to the drier zones (band B) around the reservoir margins (henceforth referred to as "shoreline"). The slope from the shoreline to the upland was determined by using a clinometer (Compton 1985). Latitude and longitude of the center of each plot were recorded using a global positioning system (Trimble GeoExplorer I, Trimble Navigation Limited, Sunnyvale, CA). Vegetation and soil were sampled in each plot during the December 1997 drawdown (Fig. 2).

Total vegetative canopy cover $(\%)$, canopy cover by species $(\%)$, extent of bare ground $(\%)$, and litter cover $(\%)$ were estimated using a modified Daubenmire method within each of twenty-five $2 \times 1-\mathrm{m}^{2}$ quadrats, which were placed at 2-m intervals along the 50-m transect, beginning at the 1-m mark (Daubenmire 1959; Fig. 3). We also noted when there was evidence of herbivory or foraging (e.g., presence or absence of pointed stumps, downed trees, piles of shavings, and dens).

Surface soil samples (100 g) were collected from 30 -cm-deep cores at regular 5-m intervals along each transect, beginning at the 0 mark (Fig. 3). Soil samples were air-dried 
before analysis of soil salinity (Rhoades 1982). They were then dried in an oven at $105{ }^{\circ} \mathrm{C}$ for 48 hours and passed through a 2 -mm sieve before analysis of soil pH (Tan 1996) and particle size (hydrometer method; Tan 1996). Total soil $\mathrm{N}, \mathrm{C}$, and $\mathrm{S}$ were determined on $0.2-\mathrm{g}$ oven-dried soil samples using a Leco-2000 CNS analyzer (LECO Corporation, St. Joseph, MN).

\section{Data Analysis}

We used $\chi^{2}$ and likelihood-ratio statistics $\left(G^{2}\right.$ test; Zar 2010) for categorical data to test differences in categorical vegetation measurements, and we used binary logistic regression (Hosmer and Lemeshow 2000) to determine the suite of independent, continuous variables (i.e., soil measurements) that best differentiated between the groupings described in Table 1 . Because our response variables were dichotomous (i.e., the presence or absence of vegetation or cover by $S$. gooddingii and T. ramosissima), multiple logistic regression was used to model patterns of shoreline vegetation and soils around the reservoir as a function of the groupings (Table 1).

Initially, we examined the magnitude of the collinearity of the vegetation and soil measurements. If 2 variables in the model had a pairwise correlation coefficient $(r)$ of $\geq 0.8$, one of the variables was removed from the model sequentially and the most significant variable was retained in the final model (Tabachnick and Fidell 2007). We used the Wald $\chi^{2}$ (Allison 1999, Tabachnick and Fidell 2007) in logistic regression analysis, which is analogous to a standard regression analysis where the model $F$ value is used to test the null hypothesis $\left(\mathrm{H}_{\mathrm{o}}\right.$ : all coefficients are equal to zero). Wald $\chi^{2}$ and its probability can be used in rejecting the null hypothesis that states that all coefficients are zero. Concordance and discordance values derived from the logistic regression analysis were used to measure the association between the predicted probabilities and to check the model's ability to predict the presence of certain vegetation cover groupings. Higher concordance corresponds to greater predictive ability of a model. We also used the standardized coefficient estimates to rank the relative importance of each of the independent variables.

Stepwise selection in SAS was used to identify independent variables for the logistic multiple regression analysis (Allison 1999, Hosmer and Lemeshow 2000). Based on iterative steps in model development, we selected the $P$ values for variable entry and elimination as 0.3 and 0.1 , respectively (Hosmer and Lemeshow 2000). The significance level $\alpha \leq 0.1$ was used to identify which soil and cover variables were retained in the final models (Nash and Bradford 2001). In some cases, transformation of predictors was carried on to improve prediction.

All data were analyzed using SAS version 9.1 (SAS Institute, Cary, NC), and variables not conforming to normality were appropriately transformed prior to analysis.

\section{Results}

Vegetation

The field survey of vegetative cover revealed several interesting patterns. Salix gooddingii and T. ramosissima were the 2 dominant species at Lake Mohave (Fig. 4). Salix gooddingii was present in the plant community in both linear, monospecific stands (circa 25-mwide strips parallel to the water's edge) and as scattered, mature individuals (ranging in height from $4 \mathrm{~m}$ to $>8 \mathrm{~m}$ ). Although $S$. gooddingii was distributed throughout bands $\mathrm{A}$ and $\mathrm{B}$, S. gooddingii cover $(\bar{x}=9.36 \%, \mathrm{SE}=0.34)$ was greatest (Fig. 4) between $6 \mathrm{~m}$ and $21 \mathrm{~m}$ (band A) from the waterline $(193.4 \mathrm{~m}$ and $195.1 \mathrm{~m}$ asl). There were more individual mature $S$. gooddingii present in band A than in band B. Salix gooddingii cover in band B was attributed to individual trees scattered within the $T$. ramosissima thickets. Indicators of herbivory, including 5 beaver lodges, were evident at all sites where $S$. gooddingii was present. There was a significant (positive) relationship between herbivory and $S$. gooddingii cover $(G=30.23, \mathrm{df}=5, P<0.001)$.

There was $T$. ramosissima in both bands; however, T. ramosissima cover increased with distance from the water's edge. Tamarix ramosissima cover was greatest in band $\mathrm{B}$, starting at $26 \mathrm{~m}$ (195.5 m asl; Fig. 4), which was attributed to the presence of dense thickets $(4 \mathrm{~m}$ tall and 25-100 m wide). Tamarix ramosissima seedlings and saplings were present in both bands; however, T. ramosissima cover between $4 \mathrm{~m}$ and $13 \mathrm{~m}$ (band B) from the waterline $(193.4 \mathrm{~m}$ and $194.3 \mathrm{~m}$ asl) was the result of several stunted, scattered individuals.

Two other native species, Prosopis pubescens Benth. (screwbean mesquite) and Pluchea 


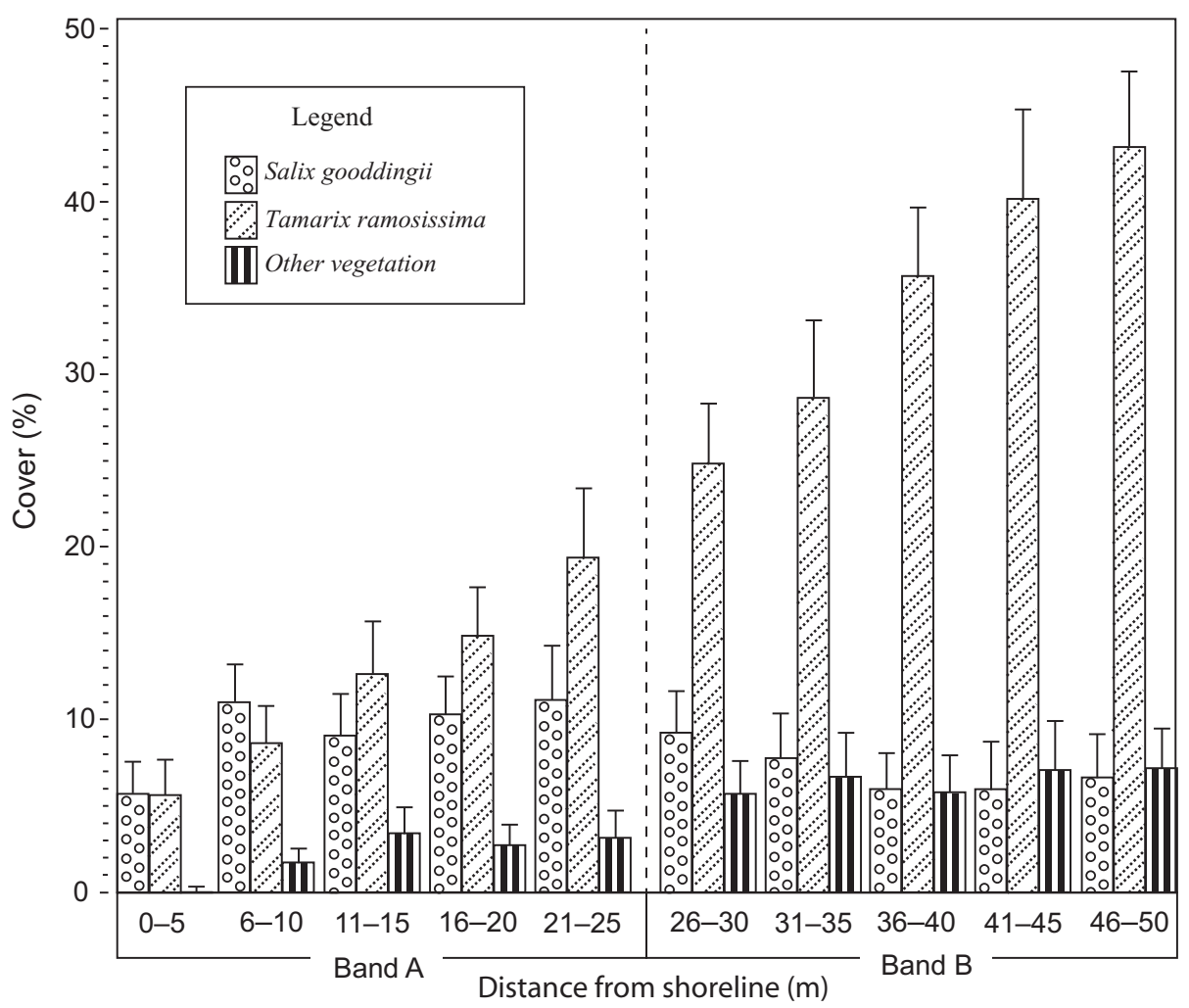

Fig. 4. Mean percent cover of the distribution of Salix gooddingii, Tamarix ramosissima, and other vegetation in 2-m intervals from the Lake Mohave shoreline (the water's edge at maximum drawdown). Other vegetation comprises Prosopis pubescens, Pluchea sericea, and Larrea tridentata. Means and standard errors are represented. Counts per meter interval are as follows:

\begin{tabular}{|c|c|c|c|c|c|c|c|c|c|}
\hline Interval & Count & Interval & Count & Interval & Count & Interval & Count & Interval & Count \\
\hline $1 \mathrm{~m}$ & 163 & $11 \mathrm{~m}$ & 155 & $21 \mathrm{~m}$ & 124 & $31 \mathrm{~m}$ & 115 & $41 \mathrm{~m}$ & 106 \\
\hline $3 \mathrm{~m}$ & 163 & $13 \mathrm{~m}$ & 149 & $23 \mathrm{~m}$ & 122 & $33 \mathrm{~m}$ & 113 & $43 \mathrm{~m}$ & 105 \\
\hline $5 \mathrm{~m}$ & 163 & $15 \mathrm{~m}$ & 142 & $25 \mathrm{~m}$ & 121 & $35 \mathrm{~m}$ & 111 & $45 \mathrm{~m}$ & 102 \\
\hline $7 \mathrm{~m}$ & 160 & $17 \mathrm{~m}$ & 136 & $27 \mathrm{~m}$ & 118 & $37 \mathrm{~m}$ & 110 & $47 \mathrm{~m}$ & 102 \\
\hline $9 \mathrm{~m}$ & 159 & $19 \mathrm{~m}$ & 130 & $29 \mathrm{~m}$ & 116 & $39 \mathrm{~m}$ & 107 & $49 \mathrm{~m}$ & 100 \\
\hline
\end{tabular}

sericea (Nutt.) Coville (arrowweed), were established in band B although they had a limited presence (cover $<20 \%$ ) in band A. Neither $S$. gooddingii seedlings nor naturally occurring $P$. fremontii was present in either band. (Although not on the study sites, 5 P. fremontii individuals planted by the Lake Mead National Recreation Area National Park Service were observed during the study.)

Soils

The average soil salinity at Lake Mohave was $4.7 \mathrm{dS} \cdot \mathrm{m}^{-1}\left(\mathrm{SE}=0.1\right.$, range $49.5-0.3 \mathrm{dS} \cdot \mathrm{m}^{-1}$; $75 \%$ of the samples were $<5.7 \mathrm{dS} \cdot \mathrm{m}^{-1}$ ). Based on the binary logistic regression of site groupings, soil salinity was significantly greater on the western bank than on the eastern bank, in sheltered coves than on exposed line beaches, and along the northern basin than along the southern basin $(P<0.001$ for all). Soil salinity was also significantly greater in band $B$ than below $(P<0.001$; Fig. 5$)$. Soil pH was significantly greater on the western bank, lower at sites with evidence of herbivory and sites with $S$. gooddingii, greater on exposed line beaches and along the southern basin, and lower in value moving upland from the water's edge (Table 2; $\bar{x}=7.9, \mathrm{SE}=0.01$, range 6.3-9.4). In contrast to salinity and $\mathrm{pH}$ measurements, nutrient levels remained uniform in both bands. 


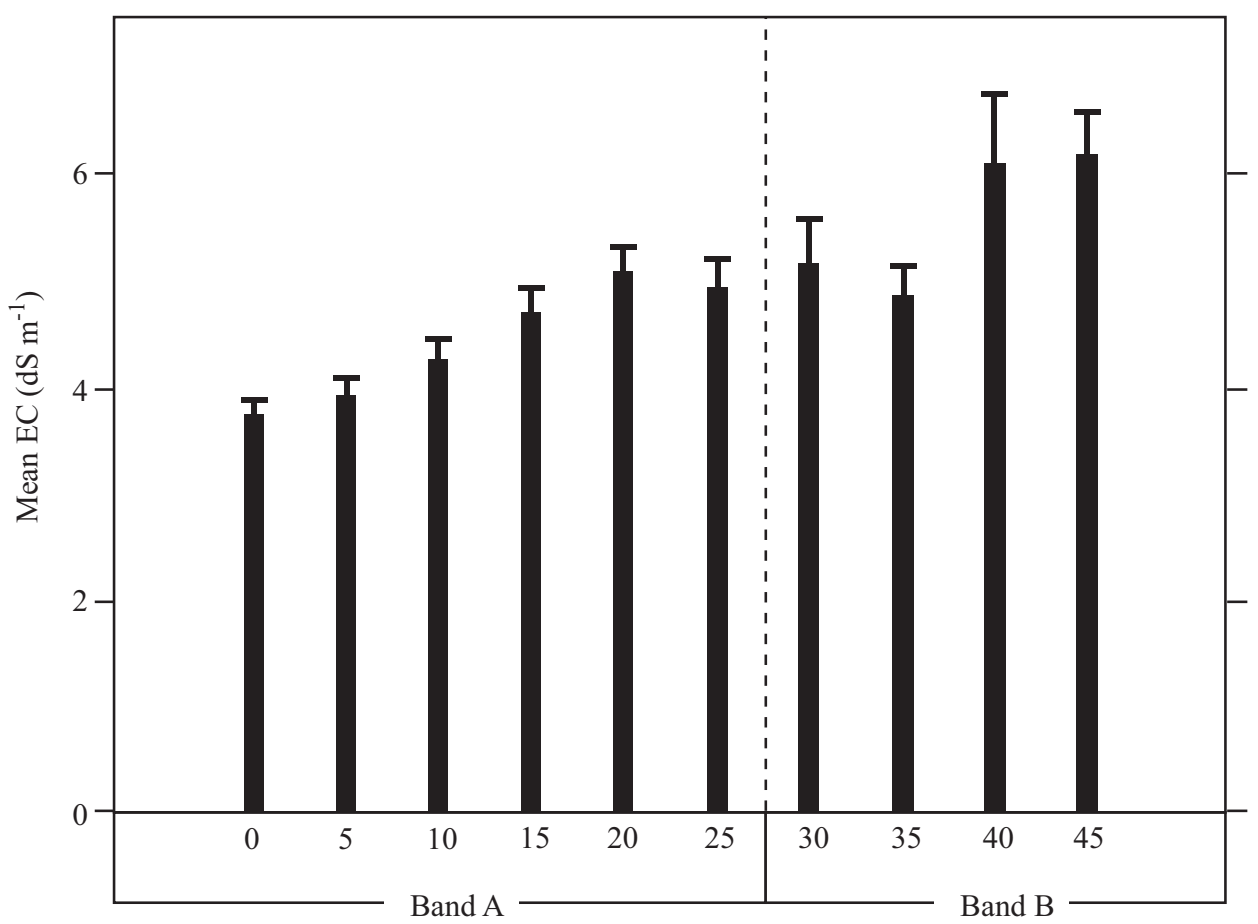

Distance from shoreline (m)

Fig. 5. Mean electrical conductivity $\left(\mathrm{dS} \cdot \mathrm{m}^{-1}\right)$ of soils from Lake Mohave in 5-m intervals from the shoreline or water's edge at maximum drawdown. Means and standard errors are represented. Counts per meter interval are as follows:

\begin{tabular}{|c|c|c|c|c|c|c|c|c|c|}
\hline Interval & Count & Interval & Count & Interval & Count & Interval & Count & Interval & Count \\
\hline $0 \mathrm{~m}$ & 170 & $10 \mathrm{~m}$ & 143 & $20 \mathrm{~m}$ & 116 & $30 \mathrm{~m}$ & 101 & $40 \mathrm{~m}$ & 95 \\
\hline $5 \mathrm{~m}$ & 154 & $15 \mathrm{~m}$ & 133 & $25 \mathrm{~m}$ & 110 & $35 \mathrm{~m}$ & 98 & $45 \mathrm{~m}$ & 90 \\
\hline
\end{tabular}

TABLE 2. Results of binary logistic regressions of site groupings (Table 1) as a function of soils variables. Analyses with $P>0.1$ are not shown. Values in bold are significant $(P \leq 0.05)$.

\begin{tabular}{|c|c|c|c|}
\hline Site grouping variable & State with greater value & Measurement & $P$ value \\
\hline \multirow[t]{4}{*}{ Bank } & West & Soil salinity & $\leq 0.001$ \\
\hline & West & $\mathrm{pH}$ & $\leq 0.001$ \\
\hline & East & $\mathrm{C}$ & $\leq 0.001$ \\
\hline & West & $\mathrm{N}$ & $\leq 0.001$ \\
\hline \multirow{2}{*}{ Salix } & Absent & $\mathrm{pH}$ & $\leq 0.001$ \\
\hline & Present & $\mathrm{N}$ & $\leq 0.001$ \\
\hline \multirow[t]{4}{*}{ Landform } & Cove & Soil salinity & $\leq 0.001$ \\
\hline & Exposed & $\mathrm{pH}$ & 0.025 \\
\hline & Exposed & $\mathrm{N}$ & 0.043 \\
\hline & Exposed & Clay & 0.060 \\
\hline \multirow[t]{3}{*}{ Herbivory } & Absent & $\mathrm{pH}$ & 0.002 \\
\hline & Present & $\mathrm{C}$ & 0.033 \\
\hline & Present & $\mathrm{N}$ & $\leq 0.001$ \\
\hline \multirow[t]{3}{*}{ Basin } & North & Soil salinity & 0.002 \\
\hline & South & $\mathrm{pH}$ & $\leq 0.001$ \\
\hline & North & C & 0.054 \\
\hline \multirow[t]{3}{*}{ Location in the drawdown } & Band A & $\mathrm{pH}$ & $\leq 0.001$ \\
\hline & Band B & Soil salinity & $\leq 0.001$ \\
\hline & Band A & $\mathrm{S}$ & 0.057 \\
\hline
\end{tabular}


TABLE 3. Variables from the stepwise logistic regression models that relate to the presence of Salix gooddingii (>5\%), Tamarix ramosissima (>10\%), and total vegetation cover $(>10 \%$; includes cover estimate of S. gooddingii, T. ramosissima, and all other vegetation). Columns containing rank values show the ranking of the relative importance of each contributing variable as measured by the standardized estimate ${ }^{\dagger}$ of that variable.

\begin{tabular}{|c|c|c|c|c|c|c|}
\hline \multirow[b]{2}{*}{ Response variables } & \multicolumn{2}{|c|}{$\begin{array}{l}\text { S. gooddingii cover } \\
(n=301)\end{array}$} & \multicolumn{2}{|c|}{$\begin{array}{l}\text { T. ramosissima cover } \\
(n=302)\end{array}$} & \multicolumn{2}{|c|}{$\begin{array}{l}\text { Total cover } \\
(n=303)\end{array}$} \\
\hline & Coefficient & Rank & Coefficient & Rank & Coefficient & Rank \\
\hline Cover by $S$. goodingii & & & $-0.0957^{* * *}$ & 1 & & \\
\hline Cover by $T$. ramosissima & $-0.0678^{* * *}$ & 2 & & & & \\
\hline Cover by litter & $0.0611^{* *}$ & 3 & $0.0498^{* *}$ & 2 & & \\
\hline Cover of sqrt (litter) & & & & & $0.9746 * *$ & 2 \\
\hline Location in the drawdown zone & & & $0.0699^{* *}$ & 3 & $0.0930 * *$ & 3 \\
\hline Soil salinity & & & $0.3061^{* *}$ & 4 & & \\
\hline Carbon & $-0.7925^{* *}$ & 4 & $-0.3185^{*}$ & 5 & & \\
\hline Sulfur & $231.0000 * *$ & 1 & & & $227.0000 * *$ & 1 \\
\hline Herbivory & & & $0.3880^{* *}$ & & $0.6528^{* *}$ & \\
\hline Clay & $0.3311^{\text {** }}$ & 5 & $-0.2100 *$ & 5 & & \\
\hline Soil pH & & & & & $2.6185^{* *}$ & 4 \\
\hline
\end{tabular}

Total soil N content $(\bar{x}=0.12 \%, \mathrm{SE}=0.01$, range 0.0009-1.26) was significantly greater on the west bank, on exposed beaches, and at sites with evidence of herbivory and presence of Salix (Table 2). Total soil C was greater on the east bank and at sites with evidence of herbivory $(\bar{x}=2.0 \%, \mathrm{SE}=0.1$, range 0.04 12.37). There were no discernible patterns for soil S content $(\bar{x}=0.010 \%, \mathrm{SE}=0.001$, range $0.00006-0.89)$ based on the site groupings. Nitrogen and sulfur levels were below instrument detection limits in $27 \%$ and $<1 \%$ of the total number of soil samples analyzed, respectively.

Patterns among Vegetation, Soil, and Environmental Variables

The multiple logistic regression model revealed a positive relationship among $S$. gooddingii, soil S, litter, and measurable clay content in the soil and a negative relationship between the presence of $T$. ramosissima and soil $\mathrm{C}$ (Table 3; Wald $\chi^{2}=55.4, P<0.0001$ ). However, there was not a model in which $S$. gooddingii presence corresponded with distance from the shoreline. The model correctly classified sampling points with the presence of $S$. gooddingii at $87.6 \%$ of the sites (i.e., concordance $=87.6)$. The absolute values of the standardized estimates (StEst) indicated the relative importance of a variable in predicting presence of $S$. gooddingii (Table 3).

The multiple logistic regression model predicting $T$. ramosissima cover revealed a nega- tive relationship between the presence of $T$. ramosissima and the presence of $S$. gooddingii, and positive relationships among T. ramosissima and litter, location on the shore, soil salinity, clay content, and herbivory (Table 3; Wald $\left.\chi^{2}=64.3, P<0.0001\right)$. Tamarix ramosissima cover was greater in band $\mathrm{B}$; that is, as the distance from the shoreline increased, the probability of finding $T$. ramosissima cover also increased (Fig. 4). Soil salinity increased with distance from shoreline. The model of $T$. ramosissima cover correctly classified sampling points with $T$. ramosissima cover at $87.5 \%$ of the points. The model of vegetative cover (by all plant species-S. gooddingii, T. ramosissima, Prosopis pubescens, and Pluchea sericea) consisted of a positive relationship among herbivory, soil S, litter (square-root transformation), location, and herbivory (Table 3). The model correctly classified sampling points with vegetative cover $(>10 \%)$ at $93.7 \%$ of the points.

\section{DisCUSSION}

Data analyses and modeling indicate that there are 3 discernible patterns in the distribution and composition of vegetation and soils around Lake Mohave. First, although S. gooddingii and T. ramosissima were both found in the more frequently inundated reaches of the drawdown (Fig. 4), they rarely co-occurred, and there were significantly more mature $S$. gooddingii individuals established than $T$. ramosissima. 
This may be attributed to the specific difference in tolerance to long-term inundation between S. gooddingii and T. ramosissima (Vandersande et al. 2001, Tallent-Halsell and Walker 2002, Glenn and Nagler 2005).

Despite the presence of mature $S$. gooddingii in the inundated zones, there were no $S$. gooddingii seedlings in the riparian plant community along the reservoir margins, perhaps because $S$. gooddingii seed release coincides with the period when the reservoir is at its highest. Released seeds fall into the water rather than on moist soil (i.e., beaches, sandbars) suitable for germination. Observations of organic debris on the shoreline indicate that seed capsules can move from tree to water to soil. Nevertheless, the S. gooddingii seeds that wash up onto beaches already vegetated with S. gooddingii or T. ramosissima probably would not germinate because they are shade-intolerant, and germinate poorly in plant litter (Sedgwick and Knopf 1989, Scott et al. 1996). In addition, $S$. gooddingii expansion by seeds into areas above the inundated zones also may be prohibited by inhibiting salt crusts under $T$. ramosissima thickets (Jackson et al. 1990).

Secondly, patterns in soil salinity and $\mathrm{pH}$ were associated with the location around the reservoir, landform type, and distance from water's edge. Geomorphic processes influence the flow of wind and water, which greatly influences the distribution of soil particles and the chemical composition of soils along the shoreline of water bodies (Gerrard 1992). Considering that the northern and southern basins differ in size, shape, and orientation, we speculate that these factors might account for differing localized wind and wave patterns, leading to stirring and mixing of soils that could account for the relatively lower concentrations of salt and nutrients in some areas along the shoreline than in others. A decrease in soil salinity on the east banks of the reservoir, along the exposed line beaches, and on shores of the southern basin may be due to strong winds, which generate waves that mechanically agitate, aerate (Whitlow and Harris 1979, Petts 1996), and flush soils. In general, the slopes on the western bank of Lake Mohave are steeper than those on the eastern bank, which may account for greater runoff velocities and flushing of soils.

Co-occurrences of vegetation and attributes of soil chemistry may reveal patterns of plant flood tolerance and soil responses to periodic inundation (Bagstad et al. 2006). However, these patterns may not reflect associations among vegetation and soils; instead, they may be an artifact of processes that occur in soils that are periodically inundated through water management. Soil salinity levels in the "dry" band B, where soils are exposed to minimal wave action, exceeded the threshold level at which vigor of P. fremontii and S. gooddingii starts to decline ( $3 \mathrm{dS} \cdot \mathrm{m}^{-1}$; Anderson 1996). Thus, these soils may be too toxic for seeds of native trees to germinate (Jackson et al. 1990). Soil rehabilitation efforts may be necessary when native vegetation is introduced above the zone of frequent inundation (Swenson and Mullins 1985, Egan et al. 1993). Frequent flushing and the periodic removal of litter and woody debris may account for the low concentrations of soil $\mathrm{N}$ and $\mathrm{P}$ in the inundated zones of the drawdown.

Finally, the significant relationship between beaver herbivory and presence of S. gooddingii suggests that beavers are attracted to sites where $S$. gooddingii is present. Finding beaver at Lake Mohave is noteworthy because it is a keystone riparian species that can considerably alter the ecosystem (Collen and Gibson 2001, Mortenson et al. 2008). Five welldeveloped beaver lodges were found hidden within dense S. gooddingii stands not visible during high water. These lodges were mostly constructed with $S$. gooddingii branches in a matrix of mud, which suggests that beaver selectively forage for S. gooddingii over T. ramosissima when constructing bank-dwellings. Even though the beaver is a natural component of southwestern riparian ecosystems and contributes to revegetation, an imbalance may result if beaver populations are allowed to increase unchecked (Collen and Gibson 2001, Rosell et al. 2005, Mortenson et al. 2008). The damage incurred by beaver foraging appears to have promoted vegetative coppicing that, in turn, increased total cover by $S$. gooddingii within the drawdown zone. In many cases, felled trees and stems had resprouted, creating dense, woody stands. In fact, the herbivory appeared to contribute both to stand regeneration and to stand destruction. During our study period, beaver felled and removed 3 mature S. gooddingii trees, the total number of native trees present within an isolated cove, in one day.

These results, when placed in the context of reservoir management, provide a basis for 
making general suggestions for management practices that may favor the conservation and expansion of the shoreline riparian ecosystem around Lake Mohave. Altering reservoir downstream flows through dams has a significant effect on riparian vegetation dynamics within both reservoirs and downstream reaches (Poff et al. 1997, Hauer and Lorang 2004, Rood et al. 2005). Within-year and among-year waterlevel variations can potentially be tools to manage shoreline plant community composition (Hill et al. 1998). Simulated flow regimes (Schmidt et al. 1998, Stromberg et al. 2007a, 2007b) meant to mimic the ecological needs of riparian taxa have been successful in the Colorado River (Zamora-Arroyo et al. 2001). Yet the timing, intensity, and duration of simulated floods are complex and, therefore, must be customized to the species being managed. Above a certain recruitment box (Mahoney and Rood 1998), native seedlings may not recruit because of drought. Below a certain recruitment box, recruitment is prevented by flooding or stream scouring. Rates of water drawdown are also critical for seedling survival. Bhattacharjee et al. (2006) suggested an optimal rate of $2 \mathrm{~cm} \cdot$ day $^{-1}$ drawdown for restoring Populus deltoides seedlings on the Rio Grande in New Mexico. Unfortunately, Tamarix chinensis has similar requirements, making it difficult to orchestrate recovery of native species while removing nonindigenous species. Furthermore, although raising the water level in reservoirs may remove $T$. chinensis, it may also negatively impact native vegetation, as Sprenger et al. $(2001,2002)$ found for P. deltoides in the Rio Grande floodplain of central New Mexico.

At Lake Mohave, one option might be to maintain high water levels from mid-May to early November over several years when $T$. ramosissima plants are releasing seed to prevent $T$. ramosissima colonization and to remove individuals already present. Flooding may reduce the abundance, distribution, and size of established T. ramosissima, while a drawdown may facilitate native seedling establishment. Drawdown starting in March (i.e., timed to match seed dispersal of indigenous species of $S$. gooddingii and $P$. fremontii) and continuing until saplings are tall enough to survive when water levels are at maximum could lead to the colonization of native riparian tree species (Levine and Stromberg 2001, Stromberg et al. 2007a, 2007b). However, manual seeding may be needed in areas where native species are no longer present or setting seeds. This approach may present difficulties because a prolonged drawdown may reduce the groundwater supporting present mature native phreatophytes (Schmidt et al. 1998).

Best management practices, which include manipulating reservoir water levels to simulate natural fluvial processes so that nonnative plant establishment is inhibited, may also flush excessive soil salts from the shoreline soils, enabling native transplants to survive (Briggs 1996). However, our suggestion to manipulate water levels and flows have been based on only the physiological needs of riparian vegetation, without consideration of the tightly regulated water storage and release cycles that are bound by Colorado River water law (Hobbs 1997). Before managers can realistically entertain alternative flow scenarios that might lead to the reestablishment of native riparian vegetation along the Colorado River and associated reservoirs, they need to investigate the legal and political ramifications of reallocating Colorado River water or rescheduling water release and storage cycles (and in doing so, impacting hydroelectric power delivery schedules).

Our objectives were to discern patterns in the existing vegetation and soils and link those patterns to environmental factors characteristic of the created (novel) ecosystem. We realize that "fixing the system back to some preexisting condition" (Hobbs et al. 2006) is unlikely. Rather, we present this information to further the common goal to enhance, augment, and restore southwestern riparian and reservoir shoreline woodlands, which may prove to be suitable surrogates for the native riparian systems that have been lost.

\section{ACKNOWLEDGMENTS}

Funding for this research was provided by the National Park Service, Lake Mead Recreation Area, and the U.S. Bureau of Reclamation, Lower Colorado Regional Office. The U.S. Environmental Protection Agency through its Office of Research and Development collaborated in the research. This manuscript has been subject to intra-agency peer review and approved for publication. Mention of trade names or commercial products does not constitute an endorsement or recommendation for use. We 
gratefully acknowledge the assistance of J. Halsell, J. Boucher, A. Halsell, C. Malsy, D. Knox, L. Guthrie, D. Bradford, P. Grossmann, D. Devitt, S. Smith, J. Haley, C. Deuser, B. Pelle, M. Rowe, J. Swett, M. Balough, A. Neale, D. Semmens, B. Schumacher, M. Butterwick, M. Mitrano, V. Dale, and several anonymous reviewers for field support, technical expertise, manuscript review, equipment, and instrumentation.

\section{Literature Cited}

ALLISON, P.D. 1999. Logistic regression using the SAS system: theory and application, SAS Institute, Inc., Cary, NC.

ANDERSON, B.W. 1996. Salt cedar, revegetation and riparian ecosystems in the Southwest. Pages 32-41 in J. Lovitch, J. Randall, and M. Kelly, editors, Proceedings of the California Exotic Pest Plant Control Council Symposium 95. Pacific Grove, CA.

Bagstad, K.J., S.J. Lite, and J.C. Stromberg. 2006. Vegetation, soils, and hydrogeomorphology of riparian patch types of dryland rivers. Western North American Naturalist 66:23-44.

Bhattacharjee, J., J.P. Taylor Jr., and L.M. Smith. 2006. Controlled flooding and staged drawdown for restoration of native cottonwoods in the Middle Rio Grande Valley, New Mexico, USA. Wetlands 26: 691-702.

Braatne, J.H., S.B. Rood, and P.E. Heilman. 1996. Life history, ecology, and conservation of riparian cottonwoods of North America. Pages 57-85 in R.F. Stettler, H.D. Bradshaw Jr., P.E. Heilman, and T.M. Hinckley, editors, Biology of Populus and its implications for management and conservation. Part I. NRC Press, National Research Council, Ottawa, Ontario, Canada.

BRIGGS, M.K. 1996. Riparian ecosystem recovery in arid lands: strategies and references. University of Arizona Press, Tucson, AZ.

Bureau of Reclamation. 2011. Davis Dam and Powerplant. [Cited 20 April 2011]. Available from: http:/ www.usbr.gov/lc/hooverdam/davisdam.html

Collen, P., And R.J. Gibson. 2001. The general ecology of beavers (Castor spp.), as related to their influence on stream ecosystems and riparian habitats, and the subsequent effects on fish - a review. Reviews of Fish Biology and Fisheries 10:439-462.

Compton, R.R. 1985. Geology in the field. John Wiley \& Sons, New York, NY.

CRIFASI, R.R. 2005. Reflections in a stock pond: are anthropogenically derived freshwater ecosystems natural, artificial, or something else? Environmental Management 36:625-639.

DaubenMiRe, R.F. 1959. Canopy coverage method of vegetation analysis. Northwest Science 33:43-64.

Egan, T.B., R.A. Chavez, and B.R. West. 1993. Afton Canyon saltcedar removal first year status report. In: L. Smith and J. Stephenson, technical coordinators, Proceedings of the Symposium on Vegetation Management of Hot Desert Rangeland Ecosystems. Phoenix, AZ.

GerRARD, J. 1992. Soil geomorphology. Chapman and Hall, London, United Kingdom.
Glenn, E.P., AND P.L. NAgLer. 2005. Comparative ecophysiology of Tamarix ramosissima and native trees in western U.S. riparian zones. Journal of Arid Environments 61:419-446.

HaLL, T.F., AND G.E. SMith. 1955. Effects of flooding on woody plants; West Sandy dewatering project, Kentucky Reservoir. Journal of Forestry 53:281-285.

HaUer, F.R., AND M.S. LoRAng. 2004. River regulation, decline of ecological resources, and potential for restoration in a semi-arid lands river in the western USA. Aquatic Sciences 66:388-401.

Hill, N.M., P.A. KedDy, AND I.C. Wisheu. 1998. A hydrological model for predicting the effects of dams on the shoreline vegetation of lakes and reservoirs. Environmental Management 22:723-736.

HoвBS, G.J., JR. 1997. Colorado water law: an historical overview. University of Denver Water Law Review 1:1-74.

Hobbs, R.J., S. Arico, J. Aronson, J.S. Baron, P. Bridgewater, V.A. Cramer, P.R. Epstein, J.J. Ewel, et al. 2006. Novel ecosystems: theoretical and management aspects of the new ecological world order. Global Ecology \& Biogeography 15:1-7.

Hoffman, D.A., AND A.R. JonEz. 1972. Lake Mead, a case history. Man-made lakes: their problems and environmental effects. Geophysical Monograph Series $17: 220-223$.

Hosmer, D.W., and S. Lemeshow. 2000. Applied linear regression. 2nd edition. John Wiley \& Sons, Inc., New York, NY.

JaCKSON, J., J.T. BaLl, AND M.R. Rose. 1990. Assessment of the salinity to tolerance of eight Sonoran desert riparian trees and shrubs. Final Report, Desert Research Institute, University of Nevada System, Biological Sciences Center, Reno, NV.

Johnson, W.C. 2002. Riparian vegetation diversity along regulated rivers: contribution of novel and relict habits. Freshwater Biology 47:749-759.

Kelting, R.W., and W.T. Penfound. 1950. The vegetation of stock pond dams in central Oklahoma. American Midland Naturalist 44:69-75.

Levine, C.M., AND J.C. Stromberg. 2001. Effect of flooding on native and exotic plant seedlings: implications for restoring south-western forests by manipulating water and sediment flows. Journal of Arid Environments 49:111-131.

MacMahon, J.A., AND F.H. Wagner. 1985. The Mohave, Sonoran and Chihuahuan deserts of North America. Pages 105-198 in A.M. Evenari, I. Noy-Meir, and D.W. Goodall, editors, Ecosystems of the world. Volume 12A, Hot deserts and arid shrublands. Elsevier, Amsterdam.

Mahoney, J.M., and S.B. Rood. 1998. Stream flow requirements for cottonwood seedling recruitmentan integrative model. Wetlands 18:634-645.

Mortenson, S.G, P.J. Weisberg, AND B.E. Ralston. 2008. Do beaver promote the invasion of non-native tamarix in the Grand Canyon riparian zone? Wetlands 28: $666-675$.

NASH, M.S., AND D.F. Bradford. 2001. Parametric and nonparametric (MARS: multivariate additive regression splines) logistic regressions for prediction of a dichotomous response variable with an example for presence/absence of an amphibian. EPA/600/R-01/ 081, Office of Research and Development, U.S. Environmental Protection Agency, Washington, DC.

National Park Service. 2011. Lake Mead National Recreation Area [web page]. [Cited 18 April 2011]. 
Available from: http://www.nps.gov/lake/planyourvisit/ weather.htm

Natural Resource Conservation Service. 1993. Range site maps, Clark County area, Nevada. U.S. Department of Agriculture.

Nilsson, C., AND K. BERGGREN. 2000. Alterations of riparian ecosystems caused by river regulation. BioScience 50:783-792.

PEnfound, W.T. 1953. Plant communities of Oklahoma lakes. Ecology 34:561-583.

PETTS, G.E. 1996. Water allocation to protect river ecosystems. Regulated rivers: research and management 12:353-365.

Poff, N.L, J.D. Allan, M.B. Bain, J.R. Karr, K.L. PesteGAARD, B.D. Richter, R.E. SPARKS, AND J.C. STROMBERG. 1997. The natural flow regime: a paradigm for river conservation and restoration. BioScience 47: 769-784.

RhoAdes, J.D. 1982. Soluble salts. Pages 167-173 in C.A Black, editor, Methods of soil analysis. American Society of Agronomy, Madison, WI.

RoElLE, J.E., AND D.N. GLADWIN. 1999. Establishment of woody riparian species from natural seedfall at a former gravel pit. Restoration Ecology 7:183-192.

Roelle, J.E., D.N. Gladwin, AND B.S. CADE. 2001. Establishment, growth, and early survival of woody riparian species at a Colorado gravel pit. Western North American Naturalist 61:182-194.

Rood, S.B, G.M. Samuelson, J.H. Bratine, C.R. GourLEY, J.M. Mahoney, AND F.M.R. Hughes. 2005. Managing river flows to restore floodplain forests. Frontiers in Ecology and the Environment 3:193-201.

Rosell, F., O. Bozsér, P. Collen, and H. Parker. 2005. Ecological impact of beavers Castor fiber and Castor canadensis and their ability to modify ecosystems. Mammal Review 35:248-276.

Schmidt, J.C., R.H. WebB, R.A. VAldez, G.R. Marzolf, AND L.E. STEvens. 1998. Science and values in river restoration in the Grand Canyon. BioScience 48: $735-747$.

Scott, M.L., J.M. Friedman, And G.T. Auble. 1996. Fluvial process and the establishment of bottomland trees. Geomorphology 14:327-339.

SEDGWICK, J.A., AND F. KNOPF. 1989. Demography, regeneration, and future projections for bottomland cottonwood community. Pages 249-266 in R.R. Sharitz and J.W. Gibbons, editors, Freshwater wetlands and wildlife. CONF-8603101, DOE Symposium Series No. 61, U.S. DOE Office of Scientific and Technical Information, Oak Ridge, TN

Smith, S.D., D.A. DevitT, A. SAla, J.R. Cleverly, and D.E. BusCH. 1998. Water relations of riparian plants from warm desert regions. Wetlands 18:687-696.

Smith, S.D., R.K. Monson, and J.E. Anderson. 1997. Physiological ecology of North American desert plants. Springer-Verlag, Berlin, Germany.
SPREnger, M.D., L.M. Smith, AND J.P. TAYLOR. 2001. Testing control of saltcedar seedlings using fall flooding. Wetlands 21:437-441.

2002. Restoration of riparian habitat using experimental flooding. Wetlands 22:49-57.

Stromberg, J.C., V.B. Beauchamp, M.D. Dixon, S.J. Lite, AND C. PARADZICK. 2007a. Importance of low-flow and high-flow characteristics to restoration of riparian vegetation along rivers in arid south-western United States. Freshwater Biology 52:651-679.

Stromberg, J.C., S.J. Lite, R. Marler, C. Paradzick, P.B. Shafroth, D. Shorrock, J.M. White, and M.S. WHite. 2007b. Altered stream-flow regimes and invasive plant species: the Tamarix case. Global Ecology and Biogeography 16:381-393.

Swenson, E.A., And C.L. Mullins. 1985. Revegetating riparian trees in southwestern riparian floodplains. Pages 135-138 in R.R. Johnson, C.D. Ziebell, D.R. Patton, P.F. Ffolliott, and R.H. Hamre, editors, Riparian ecosystems and their management: reconciling conflicting uses. General Technical Report RM-120, USDA Forest Service, Washington, DC.

TABACHNICK, B.G., and L.S. FIDELL. 2007. Using multivariate statistics. 5th edition. Allyn \& Bacon, New York.

Tallent-Halsell, N.G. 1998. Lake Mohave riparian ecology and restoration. Master's thesis, University of Nevada-Las Vegas, Las Vegas, NV.

Tallent-Halsell, N.G., and L.R. Walker. 2002. Responses of Salix gooddingii and Tamarix ramosissima to flooding. Wetlands 22:776-785.

TAN, K.H. 1996. Soil sampling, preparation and analysis. Marcel Dekker, Inc., New York, NY.

Vandersande, M.W., E.P. Glenn, and J.L. Walworth. 2001. Tolerance of five riparian plants from the lower Colorado River to salinity drought and inundation. Journal of Arid Environments 49:147-159.

Warner, R.E., AND K.M. HENDrIX, EDITORs. 1984. California riparian systems ecology, conservation, and productive management. University of Berkeley Press, Berkeley, CA.

Whitlow, T.H., AND R.W. HARRIs. 1979. Flood tolerance in plants: a state of the art review. U.S. Army Engineers Waterways Experiment Station, Vicksburg, MS.

Williams, W.D. 2000. Dryland lakes. Lakes and Reservoirs: Research and Management 5:207-212.

Zamora-Arroyo, F., P.L. Nagler, M. Briggs, D. RadtKe, H. Rodriques, J. Garcia, C. Valdes, A. Huete, AND E.P. GLENN. 2001. Regeneration of native trees in response to flood releases from the United States into the delta of the Colorado River, Mexico. Journal of Arid Environments 49:49-64.

Zar, J.H. 2010. Biostatistical analysis. 5th edition. Prentice Hall, Upper Saddle River, NJ.

Received 30 July 2009 Accepted 10 May 2011

Appendix on page 387 . 
APPEndix. Code, name, coordinates, and descriptions of the 34 sites at Lake Mohave, Nevada and Arizona, USA. Locations of sites are numbered on Fig. 1.

\begin{tabular}{|c|c|c|c|c|c|c|}
\hline Code & Name & Latitude (N), Longitude (W) & Banka $^{a}$ & Salix $\mathrm{b}$ & Landform $^{c}$ & Herbivory $^{\mathrm{d}}$ \\
\hline 1 & Middle Arizona Bay & $35^{\circ} 30^{\prime} 48^{\prime \prime}, 114^{\circ} 39^{\prime} 52^{\prime \prime}$ & $\mathrm{E}$ & $\mathrm{P}$ & $\mathrm{C}$ & $\mathrm{P}$ \\
\hline 2 & Painted Canyon Cove & $35^{\circ} 30^{\prime} 50^{\prime \prime}, 114^{\circ} 40^{\prime} 58^{\prime \prime}$ & W & A & $\mathrm{C}$ & A \\
\hline 3 & Klondike Cove & $35^{\circ} 31^{\prime} 08^{\prime \prime}, 114^{\circ} 40^{\prime} 49^{\prime \prime}$ & W & $\mathrm{A}$ & $\mathrm{C}$ & $\mathrm{A}$ \\
\hline 4 & Cove North of South Basin Cove & $35^{\circ} 22^{\prime} 46^{\prime \prime}, 114^{\circ} 36^{\prime} 28^{\prime \prime}$ & $\mathrm{E}$ & A & $\mathrm{C}$ & A \\
\hline 5 & North Glory Hole Area & $35^{\circ} 25^{\prime} 18^{\prime \prime}, 114^{\circ} 36^{\prime} 43^{\prime \prime}$ & $\mathrm{E}$ & A & $\mathrm{C}$ & A \\
\hline 6 & Carp Cove & $35^{\circ} 28^{\prime} 41^{\prime \prime}, 114^{\circ} 39^{\prime} 38^{\prime \prime}$ & $\mathrm{E}$ & $\mathrm{P}$ & $\mathrm{C}$ & $\mathrm{P}$ \\
\hline 7 & Three Mile Flat & $36^{\circ} 26^{\prime} 51^{\prime \prime}, 114^{\circ} 37^{\prime} 26^{\prime \prime}$ & $\mathrm{E}$ & $\mathrm{P}$ & $\mathrm{E}$ & $\mathrm{P}$ \\
\hline 8 & Across from Castle Cliff Light & $35^{\circ} 33^{\prime} 22^{\prime \prime}, 114^{\circ} 39^{\prime} 58^{\prime \prime}$ & W & $\mathrm{P}$ & $\mathrm{E}$ & $\mathrm{P}$ \\
\hline 9 & 2nd Cove $\mathrm{N}$ of Two Dollar Cove & $35^{\circ} 33^{\prime} 17^{\prime \prime}, 114^{\circ} 40^{\prime} 10^{\prime \prime}$ & W & $\mathrm{P}$ & $\mathrm{C}$ & $\mathrm{P}$ \\
\hline 10 & Owl Cove & $35^{\circ} 34^{\prime} 34^{\prime \prime}, 114^{\circ} 39^{\prime} 30^{\prime \prime}$ & $\mathrm{E}$ & $\mathrm{A}$ & $\mathrm{C}$ & $\mathrm{A}$ \\
\hline 11 & Twin Cove & $35^{\circ} 34^{\prime} 46^{\prime \prime}, 114^{\circ} 39^{\prime} 47^{\prime \prime}$ & $\mathrm{E}$ & $\mathrm{P}$ & $\mathrm{C}$ & $\mathrm{P}$ \\
\hline 12 & Opel Cove (North) & $35^{\circ} 35^{\prime} 28^{\prime \prime}, 114^{\circ} 39^{\prime} 51^{\prime \prime}$ & W & $\mathrm{P}$ & $\mathrm{C}$ & $\mathrm{P}$ \\
\hline 13 & Open Cove (South) & $35^{\circ} 35^{\prime} 25^{\prime \prime}, 114^{\circ} 40^{\prime} 04^{\prime \prime}$ & W & A & $\mathrm{E}$ & A \\
\hline 14 & Nevada Bay & $35^{\circ} 34^{\prime} 38^{\prime \prime}, 114^{\circ} 41^{\prime} 18^{\prime \prime}$ & W & $\mathrm{P}$ & $\mathrm{C}$ & $\mathrm{P}$ \\
\hline 15 & Nevada Bay Beach & $35^{\circ} 35^{\prime} 02^{\prime \prime}, 114^{\circ} 40^{\prime} 41^{\prime \prime}$ & W & A & $\mathrm{E}$ & $\mathrm{P}$ \\
\hline 16 & Basalt Cove & $35^{\circ} 35^{\prime} 19^{\prime \prime}, 114^{\circ} 40^{\prime} 16^{\prime \prime}$ & W & $\mathrm{P}$ & $\mathrm{C}$ & $\mathrm{P}$ \\
\hline 17 & North Arizona Bay & $35^{\circ} 31^{\prime} 07^{\prime \prime}, 114^{\circ} 39^{\prime} 25^{\prime \prime}$ & $\mathrm{E}$ & $\mathrm{P}$ & $\mathrm{E}$ & $\mathrm{P}$ \\
\hline 18 & South Arizona Bay & $35^{\circ} 31^{\prime} 03^{\prime \prime}, 114^{\circ} 39^{\prime} 27^{\prime \prime}$ & $\mathrm{E}$ & $\mathrm{A}$ & $\mathrm{E}$ & $\mathrm{P}$ \\
\hline 19 & Jeff Davis Cove & $35^{\circ} 32^{\prime} 15^{\prime \prime}, 114^{\circ} 38^{\prime} 56^{\prime \prime}$ & $\mathrm{E}$ & A & $\mathrm{C}$ & A \\
\hline 20 & Perkins Cove & $35^{\circ} 34^{\prime} 21^{\prime \prime}, 114^{\circ} 39^{\prime} 28^{\prime \prime}$ & $\mathrm{E}$ & $\mathrm{A}$ & $\mathrm{C}$ & A \\
\hline 21 & Golden Door Cove & $35^{\circ} 32^{\prime} 47^{\prime \prime}, 114^{\circ} 39^{\prime} 17^{\prime \prime}$ & $\mathrm{E}$ & $\mathrm{A}$ & $\mathrm{C}$ & $\mathrm{A}$ \\
\hline 22 & 1st Cove North of Two Dollar Cove & $35^{\circ} 33^{\prime} 06^{\prime \prime}, 114^{\circ} 40^{\prime} 14^{\prime \prime}$ & W & $\mathrm{P}$ & $\mathrm{C}$ & $\mathrm{P}$ \\
\hline 23 & Rockefeller Cove & $35^{\circ} 32^{\prime} 37^{\prime \prime}, 114^{\circ} 40^{\prime} 29^{\prime \prime}$ & W & $\mathrm{P}$ & $\mathrm{C}$ & $\mathrm{P}$ \\
\hline 24 & Beach North of Rockefeller Cove & $35^{\circ} 32^{\prime} 45^{\prime \prime}, 114^{\circ} 40^{\prime} 17^{\prime \prime}$ & W & $\mathrm{P}$ & $\mathrm{E}$ & $\mathrm{P}$ \\
\hline 25 & Box Cove & $35^{\circ} 30^{\prime} 12^{\prime \prime}, 114^{\circ} 41^{\prime} 06^{\prime \prime}$ & W & $\mathrm{A}$ & $\mathrm{E}$ & $\mathrm{A}$ \\
\hline 26 & Beach North of Three Mile Flat & $35^{\circ} 27^{\prime} 29^{\prime \prime}, 114^{\circ} 37^{\prime} 52^{\prime \prime}$ & $\mathrm{E}$ & $\mathrm{P}$ & $\mathrm{E}$ & $\mathrm{P}$ \\
\hline 27 & Sandy Cove & $35^{\circ} 28^{\prime} 15^{\prime \prime}, 114^{\circ} 40^{\prime} 48^{\prime \prime}$ & W & $\mathrm{P}$ & $\mathrm{C}$ & $\mathrm{P}$ \\
\hline 28 & Cottontail Cove & $35^{\circ} 29^{\prime} 10^{\prime \prime}, 114^{\circ} 41^{\prime} 03^{\prime \prime}$ & W & $\mathrm{P}$ & $\mathrm{C}$ & $\mathrm{P}$ \\
\hline 29 & Gremlin Cove & $35^{\circ} 23^{\prime} 40^{\prime \prime}, 114^{\circ} 38^{\prime} 54^{\prime \prime}$ & W & $\mathrm{A}$ & $\mathrm{C}$ & A \\
\hline 30 & Dead Cove & $35^{\circ} 23^{\prime} 51^{\prime \prime}, 114^{\circ} 39^{\prime} 10^{\prime \prime}$ & W & A & $\mathrm{C}$ & A \\
\hline 31 & Beach S of Nine Mile Cove & $35^{\circ} 24^{\prime} 45^{\prime \prime}, 114^{\circ} 40^{\prime} 13^{\prime \prime}$ & W & $\mathrm{A}$ & $\mathrm{E}$ & $\mathrm{A}$ \\
\hline 32 & Beach $\mathrm{N}$ of Nine Mile Cove & $35^{\circ} 25^{\prime} 05^{\prime \prime}, 114^{\circ} 40^{\prime} 34^{\prime \prime}$ & W & $\mathrm{A}$ & $\mathrm{E}$ & $\mathrm{A}$ \\
\hline 33 & Beach $\mathrm{N}$ of Six Mile Cove & $35^{\circ} 27^{\prime} 18^{\prime \prime}, 114^{\circ} 40^{\prime} 36^{\prime \prime}$ & W & $\mathrm{P}$ & $\mathrm{E}$ & $\mathrm{P}$ \\
\hline 34 & Bill Gayes Cove & $35^{\circ} 27^{\prime} 26^{\prime \prime}, 114^{\circ} 40^{\prime} 41^{\prime \prime}$ & W & $\mathrm{P}$ & $\mathrm{E}$ & $\mathrm{P}$ \\
\hline
\end{tabular}

${ }^{\mathrm{a} B a n k}=$ east $(\mathrm{E})$ or west $(\mathbf{W})$

${ }^{\mathrm{b} S a l i x}=$ presence $(\mathrm{P})$ or absence $(\mathrm{A})$ of Salix gooddingii at site.

${ }^{\mathrm{C}}$ Type $=$ exposed $(\mathrm{E})$ line or sheltered cove beach $(\mathrm{C})$.

dHerbivory = presence (P) or absence (A) of herbivory at site. 